\title{
VARIATIONS IN BENTHIC MACROINVERTEBRATEFAUNA AS INDICATOR OF LAND USE IN THE KEN RIVER, CENTRAL INDIA
}

\section{Prakash Nautiyal $^{1}$ \& Asheesh Shivam Mishra ${ }^{2}$}

${ }^{1,2}$ Aquatic Biodiversity Unit, Department of Zoology \& Biotechnology, H. N. B. Garhwal (Central) University, Srinagar, Garhwal, Uttarakhand 246174, India

${ }^{1}$ lotic.biodiversity@gmail.com, ${ }^{2}$ shivam_a2000@yahoo.co.in (corresponding author)

\begin{abstract}
Examination of benthic macroinvertebrates in semi-natural, urban and agricultural land use along the highland Ken River in central India reveals a significantly higher density in semi-natural compared with other two landuse. Insects dominate the fauna at seminatural (90\%) and urban locations (93\%) compared to agriculture sites (48\%) where where annelid share increases to $32 \%$. The seminatural location characterized by rocky substrate support high relative abundance of Caenidae and Neoephemeridae. Their abundance decreases at urban locations. Brachycentridae, Chironomidae, Glossocolecidae, Nephthydae, Thiaridae and Corbiculidae increased at urban and agriculture locations characterized by small-sized sediments, suggesting important role for substrate also. Ordination shows that the Caenidae and Heptageniidae are characteristic at semi-natural location, Leptophlebiidae, Hydropsychidae, Glossosomatidae at urban while Thiaridae and Chironomidae at agricultural locations. Functionally, the collectors dominate the fauna, as all three landuse, especially large tracts of agriculture, are a continuous source of particulate organic matter (POM) in the river.
\end{abstract}

Keywords: Caenidae, collectors, continuum, heterotrophic, plateau river, substrate, urban.

\begin{abstract}
Hindi Abstract
सारः मध्य-भारत में हाइलैंड केन नदी के किनारे अर्द्ध-प्राकृतिक, शहरी और कृषि भूमि के उपयोग में तल में रहने वाले मैक्रोअकशेरूकीय के अध्ययन से पता चलता है के दो अन्य भूमि उपयोग की तुलना में अर्द्ध-प्राकृतिक में घनत्व सांख्यिकीय रूप से अधिक महत्वपूर्ण है. कीट की प्रचुरता, कृषि भूमि के उपयोग में ( $48 \%$, जहां एनेलिड का अनुपात $32 \%$ तक बढ़ता है) की तुलना में अर्द्ध-प्राकृतिक (90\%) और शहरी स्थानों $(93 \%)$ में अधिक है. अर्द्ध-प्राकृतिक स्थान जहां चट्टानी सब्सट्रेट प्रचुर है, सेनिडेई और नियोएफिमरिडेई की बहुतायत से होती है. उनकी बहुतायत शहरी स्थानों पर घट जाती है. ब्रेकिसेनट्रिडेई, काईरोनोमिडेई, ग्लोस्सोकोलेसिडेई, नेफ्थायिडेई, थिअरिडेई और कोर्बिकुलिडेई की शहरी और कृषि स्थानों पर (जहां की विशेषता छोटे आकार के अवसाद है), वृद्धि से पता चलता है, सब्सट्रेट की भूमिका भी महत्वपूर्ण है. ऑर्डिनेशन से पता चलता है, सेनिडेई और हेप्तजेनीडेई अर्द्ध प्राकृतिक स्थान के लक्षण हैं, लेप्तोफ्लेबीडेई, हाइद्रोप्साईकिडेई, ग्लोस्सोकोलेसिडेई शहरी में, जबकि थिअरिदए और कआइरोनोमिडेई कृषि स्थानों के लक्षण हैं. कार्यात्मक दृष्टि से जीव में कलेक्टर सभी भूमि उपयोग में प्रचुर हैं, जो नदी में कार्बनिक पदार्थ कण (POM) के सतत स्रोत हैं, विशेष रूप से कृषि.
\end{abstract}

DOI: http://dx.doi.org/10.11609/JoTT.03211.4096-105 | ZooBank: urn:Isid:zoobank.org:pub:468576BF-A0C8-4DC3-AF96-7D95FC3C538B

Editor: K.G. Sivaramakrishnan, Madras Christian College, Chennai, India

Date of publication: 26 April 2013 (online \& print)

Manuscript details: Ms \# 03211 | Received 19 May 2012 | Final received 12 March 2013 | Finally accepted 20 March 2013

Citation: Nautiyal, P. \& A.S. Mishra (2013). Variations in benthic macroinvertebratefauna as indicator of land use in the Ken River, central India. Journal of Threatened Taxa 5(7): 4096-4105; http://dx.doi.org/10.11609/JoTT.03211.4096-105

Copyright: @ Nautiyal \& Mishra 2013. Creative Commons Attribution 3.0 Unported License. JoTT allows unrestricted use of this article in any medium, reproduction and distribution by providing adequate credit to the authors and the source of publication.

Funding: The present study was conducted with the financial support given by University of Allahabad during D.Phil Degree programme of second author (ASM).

Competing Interest: None.

Acknowledgements: The authors acknowledge the academic support granted by Prof. H.R. Singh, Former-Vice Chancellor, University of Allahabad and Prof J.P. Bhatt, Head, Department of Zoology, H.N.B. Garhwal University, Srinagar. The second author (ASM) is thankful to U.G.C., New Delhi for providing fellowship during the D. Phil. programme from the University of Allahabad.

Author Contribution: PN has given the shape of the manuscript by critical evaluation at each step while data collection and analysis was performed by ASM.

Author Details: Dr. Prakash NaUtiYal, Professor. Major contributions: Threats to mahseer fish species of Gangetic drainage, their habitats and ecosystem, biodiversity thereof, in the Himalaya and Bundelkhand region and e-flows for ecological integrity.

DR. ASHeESH SHIVAM MISHRA is working as a guest faculty. He has worked in many projects funded by UCOST (Dehradun), MoEF and ICAR (New Delhi) and also worked as Project Scientist in GRBMP (IIT Kanpur). He is involved in the study of aquatic biodiversity in Himalaya and Central Highlands ecoregions.
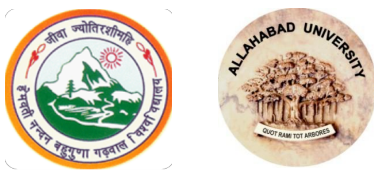


\section{INTRODUCTION}

Land use affects the distribution of benthic macroinvertebrate fauna along the river continuum and are hence useful indicators of this stress (Richards et al. 1993; Roth et al. 1996; Hershey \& Lamberti 1998; Allan 2004). This knowledge pertains to temperate streams. Such an impact has been scarcely investigated in tropical India (Singh \& Nautiyal 1990; Subramanian et al. 2005; Nautiyal \& Mishra 2011). This study examines the distribution of riverine macroinvertebrate fauna with respect to differential land use in Bundelkhand region (central India) where the ambitious Ken-Betwa River link is proposed for efficient water use. The excess water from the Ken basin will be diverted to the Betwa (NWDA 2006). The construction of impounding, diverting and linking structures will alter the present channel morphology, flow regimes and the existing landuse. The present study will serve as reference to the impacts of the 'river links' on benthic macroinvertebrate communities and hence the river ecosystem. The present study examines: (a) density, richness and composition of benthic macroinvertebrate fauna in different land use and (b) how the current land use practices in the river Ken affect longitudinal variations in the richness and composition of this community.

\section{MATERIALS AND METHODS}

\section{Study area}

The Chambal, Betwa, Ken, Tons and Son are the major right bank tributaries of the Yamuna and Ganga. They rise in central India and flow northwards across the Bundelkhand Plateau (central highland eco-region) into the Gangetic Plains. The Ken arises from the northwest slopes of the Kaimur Hills (Vindhyan ranges) in the Jabalpur District of Madhya Pradesh. It flows ca. $427 \mathrm{~km}$ from $550 \mathrm{~m}$ to $86 \mathrm{~m}$ (NWDA 2006), a gradient of $<1 \mathrm{~km}$ 1. Semi-natural conditions prevail from the source to Panna (S1, Fig. 1), where forested landscape exists along a large part of the river including the Panna National Park, and only a small segment is under agriculture land use. Human settlements are small (villages), except the urbanised location at Banda. Agriculture is the major land use along both banks of the remaining river (Images 1a-c). The semi-natural, urban and agriculture land use selected for the study at Panna (S1), Banda (S2) and Chilla (S3), respectively fall in the upper, middle and lower stretches of the river (Fig. 1). The maximum depth of the river was $7 \mathrm{~m}$ at $\mathrm{S} 1,0.6 \mathrm{~m}$ at $\mathrm{S} 2$, and $7.5 \mathrm{~m}$ at $\mathrm{S} 3$.

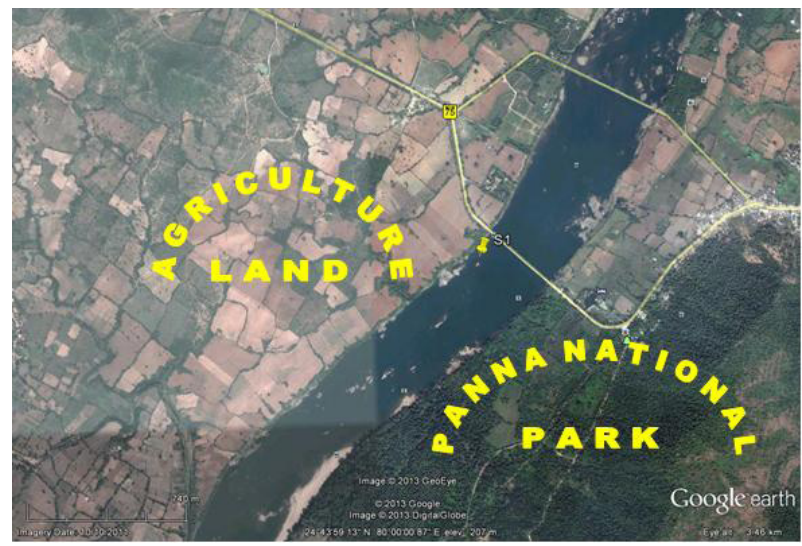

Image 1a. Semi-natural land use at station $\mathbf{S 1}$ indicated by yellow pin: Left bank of the river is un-shaded where agriculture prevails, while cliff-like right bank consists of overhanging vegetation of the Panna National Park (PNP).

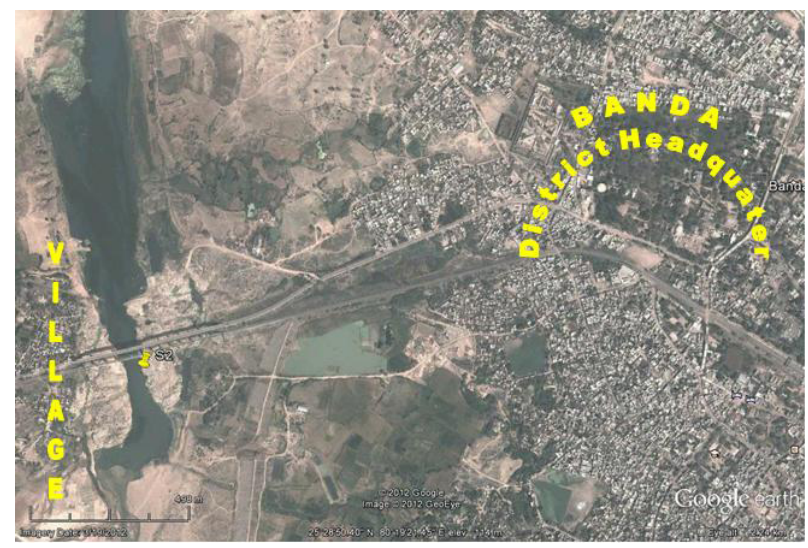

Image 1b. Urban land use at station S2 indicated by yellow pin: Agriculture and village exist on the left bank while the right bank has agriculture land and the Banda City (District headquarters) little away from the river (indicated in the upper right margin of the photograph).

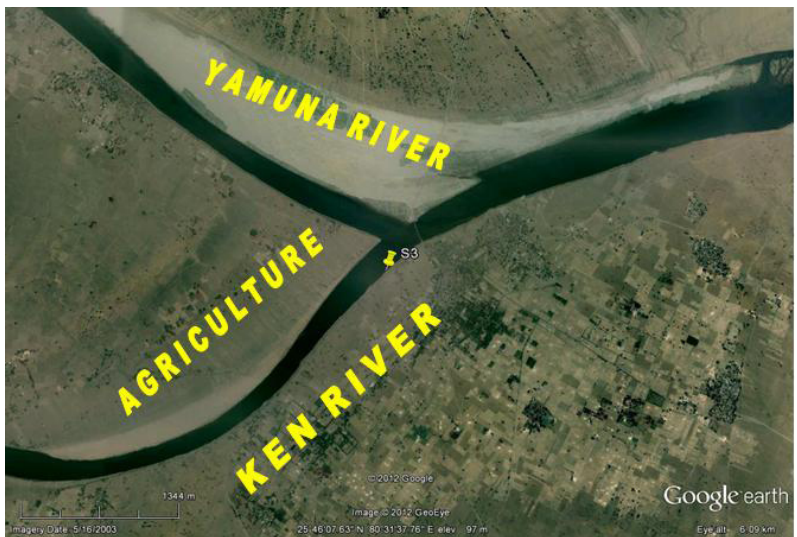

Image1c. Agriculture land use at station S3 indicated by yellow pin: Agriculture land use prevails on both banks of the river. 


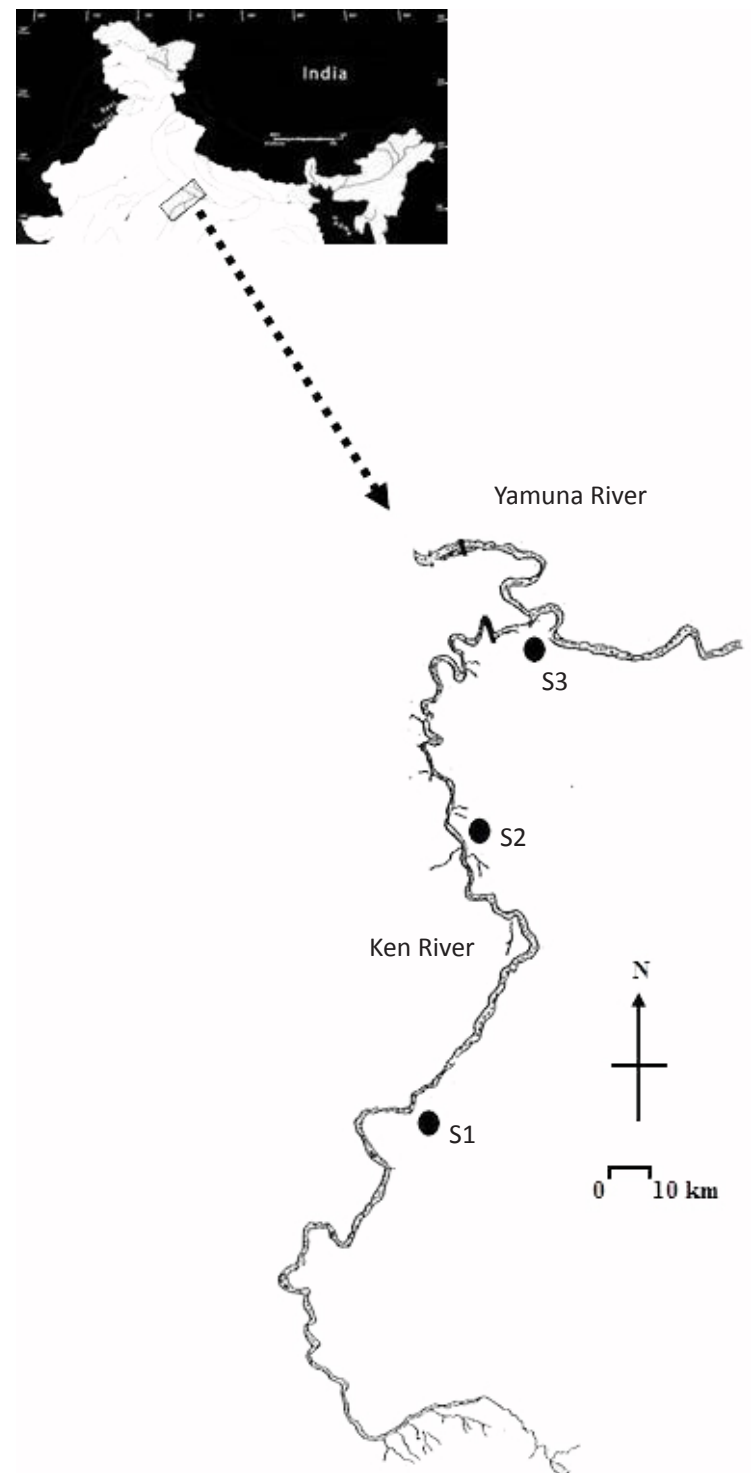

Figure 1. Location of the Ken River in India and sampling stations (S1 to S3) selected for the study.

However, samples were taken at $0.6 \mathrm{~m}$ at all stations. Stony substrate occurred at S1 and S2, while silt-claysand at S3 (Table 1). The semi -natural, agriculture and discharge of municipal sewage from the Banda City landuse are the sources of particulate organic matter (POM) in the river.

In the Bundelkhand Plateau, the dry-period extends for nine months (October-June) and wet period for three months during monsoon (July-September) (Unni 1996; Vombatkere 2005). As faunal composition remains relatively stable in the dry period than during floods (Ormerod et al. 1994; Jüttner et al. 2003), onetime intensive sampling (20 quadrants per station) was made during a part of the dry-period considered suitable
Table 1. The geographical co-ordinates, physical characteristics, land use and substrate combinations found at each sampling location in the Ken river. The substrate combination at each location begins with dominant substrate type.

\begin{tabular}{|c|c|c|c|}
\hline Station & Panna (S1) & Banda (S2) & Chilla (S3) \\
\hline $\begin{array}{l}\text { Distance from } \\
\text { source (Km.) }\end{array}$ & 142.5 & 267.5 & 340 \\
\hline Latitude $(\mathrm{N})$ & $24^{\circ} 44^{\prime} 17^{\prime \prime}$ & $25^{\circ} 28^{\prime} 38^{\prime \prime}$ & $25^{\circ} 46^{\prime} 15^{\prime \prime}$ \\
\hline Longitude (E) & $80^{\circ} 0^{\prime} 41^{\prime \prime}$ & $80^{\circ} 18^{\prime} 51^{\prime \prime}$ & $80^{\circ} 31^{\prime} 36^{\prime \prime}$ \\
\hline Altitude ( $m$ asl) & 200 & 95 & 86 \\
\hline Landuse type & $\begin{array}{l}\text { LB (PNP) } \\
\text { RB (Ag) }\end{array}$ & $A-C$ & EA \\
\hline $\begin{array}{l}\text { Substrate } \\
\text { combination }\end{array}$ & $B, R, C, P, G$ & C, P, G, B, S, Si & $\mathrm{Cl}, \mathrm{Si}$ \\
\hline $\begin{array}{l}\text { Water } \\
\text { temperature }\left({ }^{\circ} \mathrm{C}\right)\end{array}$ & $16.5-22$ & $17.0-24.5$ & $20.5-27$ \\
\hline $\begin{array}{l}\text { Current velocity } \\
\left(\mathrm{cm} \mathrm{s}^{-1}\right)\end{array}$ & $10-60$ & $2.0-12$ & 1.0 \\
\hline $\mathrm{pH}$ & $7.0-7.2$ & $7.2-7.5$ & $7.2-7.5$ \\
\hline Total taxa & 14 & 15 & 11 \\
\hline
\end{tabular}

Acronyms: B - Boulder; C - Cobble; Cl - Clay; G - Gravel; P - Pebble; S - Sand; R - Rock; Si - Silt; PNP - Protected National Park; Ag - Agriculture; AC - Agriculture City; EA - Extensive Agriculture; LB - Left bank; RB - Right bank.

for studies such as the present one (Corkum 1989, 1991). The benthic macroinvertebrates were sampled from December to March because certain stretches of the river dry-up from March to June, and disrupt the continuum. The monsoon floods replenish the nutrients and POM needed to sustain the essential food chains in the ecosystem.

Sampling procedures at each station involved lifting stones (boulder, cobble, pebble, gravel) sieving clay and silt from $0.09 \mathrm{~m}^{2}$ area in different flows (turbulent, swift, slow, placid), cleaning the substrate to obtain the macroinvertebrate fauna and preserving in 5\% formalin for further analysis. Since the right bank was inaccessible at S1 due to cliff like terrain, only the left bank was sampled at this location. Both the banks were sampled at S2 and S3. Broad taxonomic classifications (family level) are acceptable to develop the empirical relationships involving benthic invertebrates in a large study area (Corkum 1989). Therefore, the taxa were identified up to the family level by using standard literature Edmondson (1959), Edington \& Hildrew (1995), and Nesemann et al. (2004).

Counts were made for each of the 20 quadrants to obtain total (mean, median) density (indiv. $\mathrm{m}^{-2}$ ), relative abundance (as \%) and the faunal composition at each location. The significant differences in total density was determined among different land use patterns as well 
as between two successive patterns of landuse at family level through Kruskal-Wallis $(\mathrm{H})$, and Mann -Whitney (U) test (PAST software <http://nhm2.uio.no/norlex/ past $>$ ). The impact of land use on functional state of the river was determined using the functional feeding groups (Cotta-Ramusino et al. 1995; Cummins et al. 2005). The significant and non-significant association between a particular land use was determined by chisquare test. Principal component analysis (PCA) helps to determine the associated taxa at each location (Braak \& Smilauer 2002). PCA was computed from the counts of invertebrate fauna from each quadrant.

\section{RESULTS}

The physiographic conditions of the river, the altitude, gradient, water current velocity and the combination of substrate differ slightly at each location (Table 1). The water temperature increases gradually and the current velocity decreases, as the river flows from high to low elevation from S1 to S3 in the alluvial Gangetic Plains.

The benthic fauna belongs to three phylaarthropods, molluscs and annelids. The arthropods are represented only by classes Insecta, the molluscs by classes Gastropoda and Pelecypoda, while the annelids by classes Oligochaeta and Polychaeta. However, the insects constitute as high as $93 \%$ of the total fauna at S2 to a low of $48 \%$ at S3, others accounting for the remaining share at each location (Fig. 2). The faunal richness varies at S1 (15), S2 (14) and S3 (12), representing semi-natural, urban and agriculture land use (Table 1). While the richness decreases from S1 to S3, the mean total density of benthic fauna decreases considerably from S1 to S2 but increases at S3. The increase and decrease in their share corresponds with that of the total density.

There is a notable similarity in the fauna among the semi-natural and urban land use compared with the agricultural land use (Tables $2 \& 3$ ). Thus, most of the taxa occur at all locations, but some taxa present at S1 and S2 are absent at S3, viz., Neoephemeridae, Leptophlebiidae and Hydropsychidae.

Moreover, Glossocolecidae and Nephthydae (polychaete worms) present at S1 are absent at S2 but reappear at S3. However, the qualitative similarity does not conform with quantitative data because the density of the most abundant taxon between two different patterns of landuse varies significantly from S1 to S3 (Table 2). Few taxa showed gradual increase or decrease (Chironomidae, Corbiculidae,

Table 2. Benthic macroinvertebrate community: Total density (mean, SE) in different land uses in Ken River. Density is calculated from 20 quadrants data for each land use. Mann-Whitney tests (U-test) determines significant difference in mean densities (indiv. $\mathrm{m}^{-2}$ ) in the families present for pair of land use in the Ken River. (df = degree of freedom).

\begin{tabular}{|c|c|c|c|c|c|c|c|}
\hline \multirow{2}{*}{ Family } & \multirow{2}{*}{ S1 } & \multirow{2}{*}{ S2 } & \multirow{2}{*}{ S3 } & \multirow{2}{*}{$\begin{array}{c}\text { Final } p \text {-value } \\
\text { 'H'-test }\end{array}$} & \multicolumn{3}{|c|}{ Final $p$-value 'U'-test } \\
\hline & & & & & S1-S2 & S2-S3 & S3-S1 \\
\hline Leptophlebiidae & $8.25(2.23)$ & 47.85(17.9) & 0 & 0.01048 & 0.3557 & 0.0009293 & 0.0003846 \\
\hline Caenidae & $105.1(14.46)$ & $0.55(0.55)$ & $1.1(0.75)$ & $3.258 \mathrm{e}-09$ & 1.183E-08 & 0.5734 & $1.718 \mathrm{E}-08$ \\
\hline Neoephemeridae & $75.35(9.41)$ & $2.2(1.28)$ & 0 & $2.586 \mathrm{E}-09$ & $2.024 \mathrm{E}-08$ & 0.08056 & 7.619E-09 \\
\hline Baetidae & $11(6.86)$ & $20.35(5.60)$ & $0.55(0.55)$ & 0.00716 & 0.01219 & 0.0002073 & 0.2753 \\
\hline Hydropsychidae & $1.1(0.75)$ & $22.55(7.29)$ & 0 & 0.001579 & 0.00068 & $6.508 \mathrm{E}-05$ & 0.1624 \\
\hline Chironomidae & $8.25(1.93)$ & $13.2(4.11)$ & $39.05(11.63)$ & 0.1889 & 0.6749 & 0.1491 & 0.07875 \\
\hline Helidae & $12.1(4.13)$ & $2.2(1.28)$ & $25.85(7.15)$ & 0.008473 & 0.03094 & 0.0006761 & 0.1384 \\
\hline Gomphidae & $6.6(3.42)$ & $17.05(6.6)$ & $25.85(5.82)$ & 0.00982 & 0.1613 & 0.07714 & 0.001304 \\
\hline Glossocolecidae & $6.6(4.54)$ & 0 & $9.35(2.90)$ & 0.04986 & 0.1624 & 0.0009168 & 0.03732 \\
\hline Nepthydae & $6.05(4.33)$ & 0 & 40.14(9.03) & 5.063E-06 & 0.1626 & $3.211 \mathrm{E}-07$ & $3.102 \mathrm{E}-05$ \\
\hline Thiaridae & $9.9(3.81)$ & $4.4(1.87)$ & $64.34(13.92)$ & 5.803E-05 & 0.4152 & $3.169 \mathrm{E}-05$ & 0.0002302 \\
\hline Corbiculidae & $5.5(2.03)$ & $7.15(2.15)$ & $14.3(7.65)$ & 0.7798 & 0.6051 & 0.8085 & 0.4404 \\
\hline $\begin{array}{l}\text { Total mean density } \pm S E \\
\text { (indiv. } \mathrm{m}^{-2} \text { ) }\end{array}$ & $284(29.01)$ & $158.4(22.48)$ & $248.6(27.51)$ & 0.001177 & 0.00038 & 0.0137 & 0.2611 \\
\hline Range (Minimum- Maximum) & $99-605$ & $44-451$ & $33-506$ & & & & \\
\hline $\begin{array}{l}\text { Assemblages forming taxa and } \\
\text { their relative abundance (as \%) }\end{array}$ & $\mathrm{CN}-\mathrm{NE} ; 37-27$ & LP-HY; 30-14 & $\begin{array}{l}\text { TH-CH-NP; } \\
26-16-16\end{array}$ & & & & \\
\hline
\end{tabular}

Acronyms: CH - Chironomidae; CN - Caenidae; HY - Hydropsychidae; LP - Leptophlebiidae; NE - Neoephemeridae; NP - Nepthydae; TH - Thiaridae. 
Table. 3 Benthic macroinvertebrate fauna with respect to their Functional Feeding Groups (FFG) for different land uses in the Ken River. Families have been grouped on the basis of their functional role in the ecosystem into FFG, viz., scraper, gathering collectors, filtering collectors, predators. Each family is expressed as number of individuals in the total count from $\mathbf{2 0}$ quadrants at each location.

\begin{tabular}{|c|c|c|c|}
\hline \multirow{2}{*}{$\begin{array}{l}\text { Functional Feeding } \\
\text { Family/groups }\end{array}$} & \multicolumn{3}{|c|}{$\begin{array}{l}\text { Number of individuals of each family (FFG) } \\
\text { at each station }\end{array}$} \\
\hline & S1 & S2 & S3 \\
\hline Caenidae & 191 & 1 & 2 \\
\hline Neoephemeridae & 137 & 4 & 0 \\
\hline Leptophlebiidae & 15 & 87 & 0 \\
\hline Baetidae & 20 & 37 & 1 \\
\hline Chironomidae & 15 & 24 & 71 \\
\hline Heleidae & 22 & 4 & 47 \\
\hline $\begin{array}{l}\text { Oligochaeta } \\
\text { (Glossoscolecidae) }\end{array}$ & 12 & 0 & 17 \\
\hline Gathering Collectors & 412 & 157 & 138 \\
\hline Brachycentridae & 15 & 21 & 0 \\
\hline Hydropsychidae & 2 & 41 & 0 \\
\hline Polychaeta (Nephthydae) & 11 & 0 & 73 \\
\hline Pelecypoda (Corbiculidae) & 10 & 13 & 26 \\
\hline Filtering Collectors & 38 & 75 & 99 \\
\hline Glossosomatidae & 0 & 4 & 0 \\
\hline Thiaridae & 18 & 8 & 117 \\
\hline Scraper & 20 & 14 & 117 \\
\hline Rhyacophilidae & 6 & 1 & 0 \\
\hline Tabanidae & 7 & 0 & 23 \\
\hline Dytiscidae & 0 & 1 & 18 \\
\hline Gomphidae & 12 & 31 & 47 \\
\hline Agrionidae & 0 & 0 & 7 \\
\hline Predators & 25 & 33 & 95 \\
\hline Miscellaneous groups & 40 & 6 & 3 \\
\hline $\begin{array}{l}\text { Total Number of } \\
\text { Individuals }\end{array}$ & 531 & 283 & 452 \\
\hline
\end{tabular}

Gomphidae). Except for Helidae, other taxa either declined (Caenidae, Neoephemeridae) or increased abruptly (Leptophlebiidae, Thiaridae, Hydropsychidae, Nephthydae) (Fig. 3). The benthic macroinvertebrate assemblages varied; Caenidae - Neoephemeridae at S1; Leptophlebiidae - Hydropsychidae - Glossosomatidae at S2 and Thiaridae - Chironomidae- Nephthydae at S3 (Table 2, Plate I).

\section{Associated taxa from each pattern of land use in the Ken}

The cumulative percentage variance of species data for PCA axes 1 and 2 is $51.8 \%$ and $83.7 \%$, respectively; the
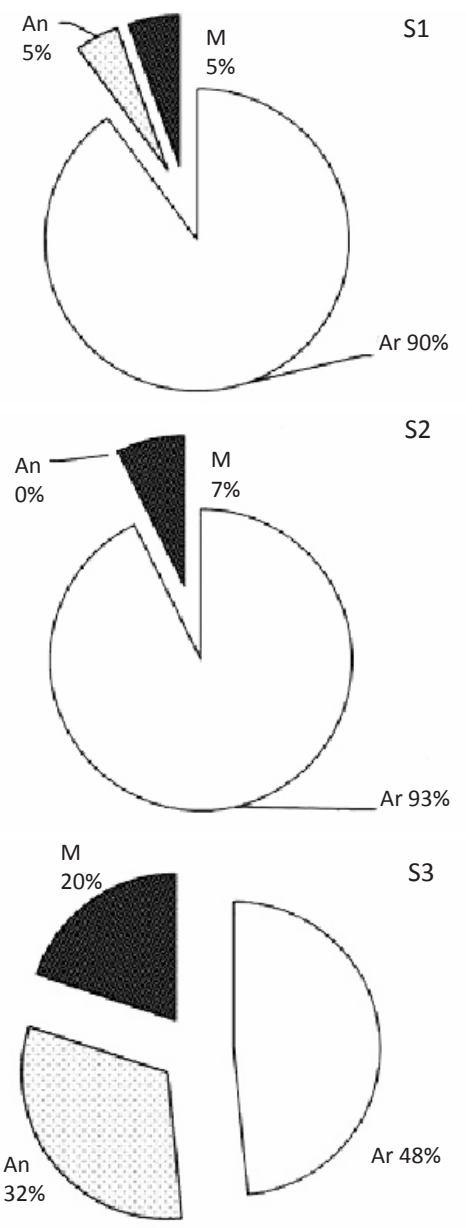

Figure 2. Percentage composition of higher taxonomic groups (An Annelida; Ar - Arthropoda; M - Mollusca) at stations S1 to S3, in the Ken River.

eigen values are 0.518 and 0.318 (Canonical eigen value 1.000). Ordination analysis (PCA) indicates characteristic taxa for each land use; Caenidae-Heptageniidae in the semi-natural conditions at S1, LeptophlebiidaeHydropsychidae-Glossosomatidae for urban land use at S2 and Thiaridae (gastropod)-Chironomidae for agriculture land use at S3 (Fig. 4). This observation supports the assemblage pattern for each land use (Table 1). Functionally, collector community prevails all along the river from S1 to S3 (Table 3). These relationships are expected to be similar throughout the dry season also and are hence, applicable to a large part of the year except the monsoon. 

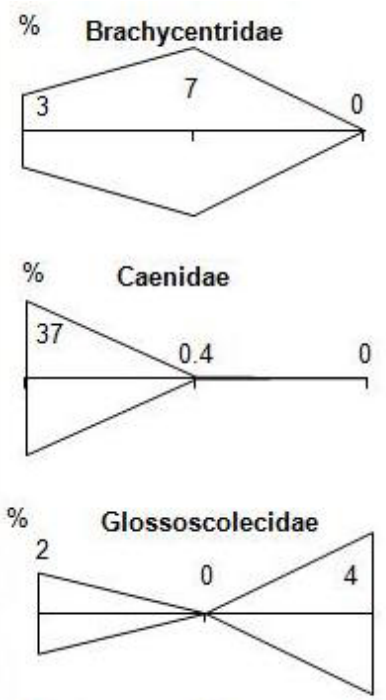

S1

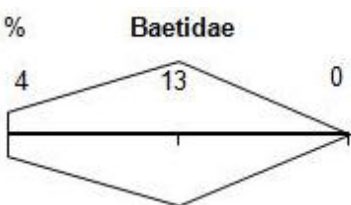

$\% \quad$ Chironomidae
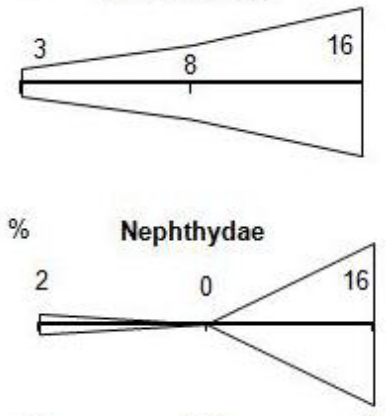

S1

S2
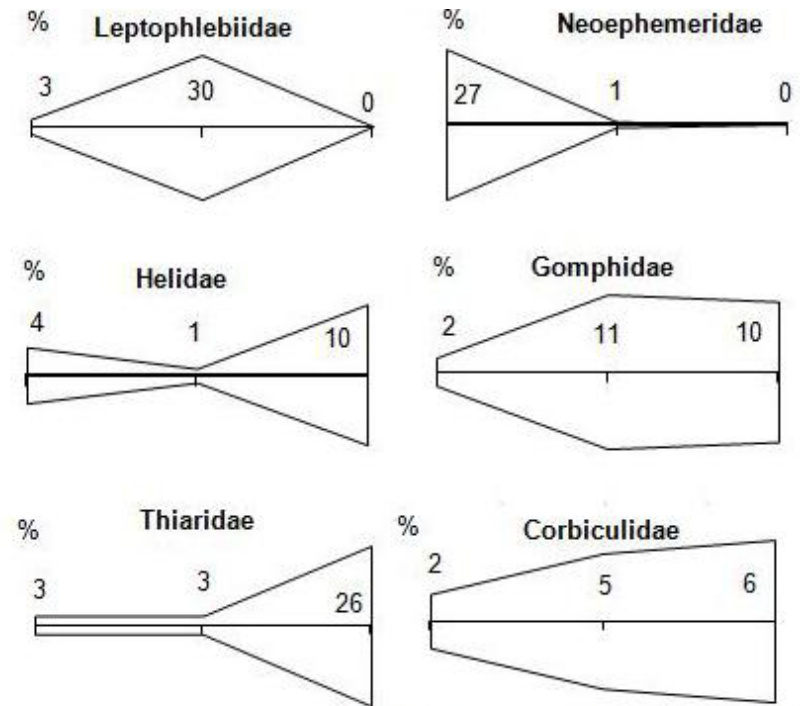

S3 S1

S2

S3 S1

Figure 3. Few taxon indicates gradual increase or decrease along the length of the river with respect to land use.

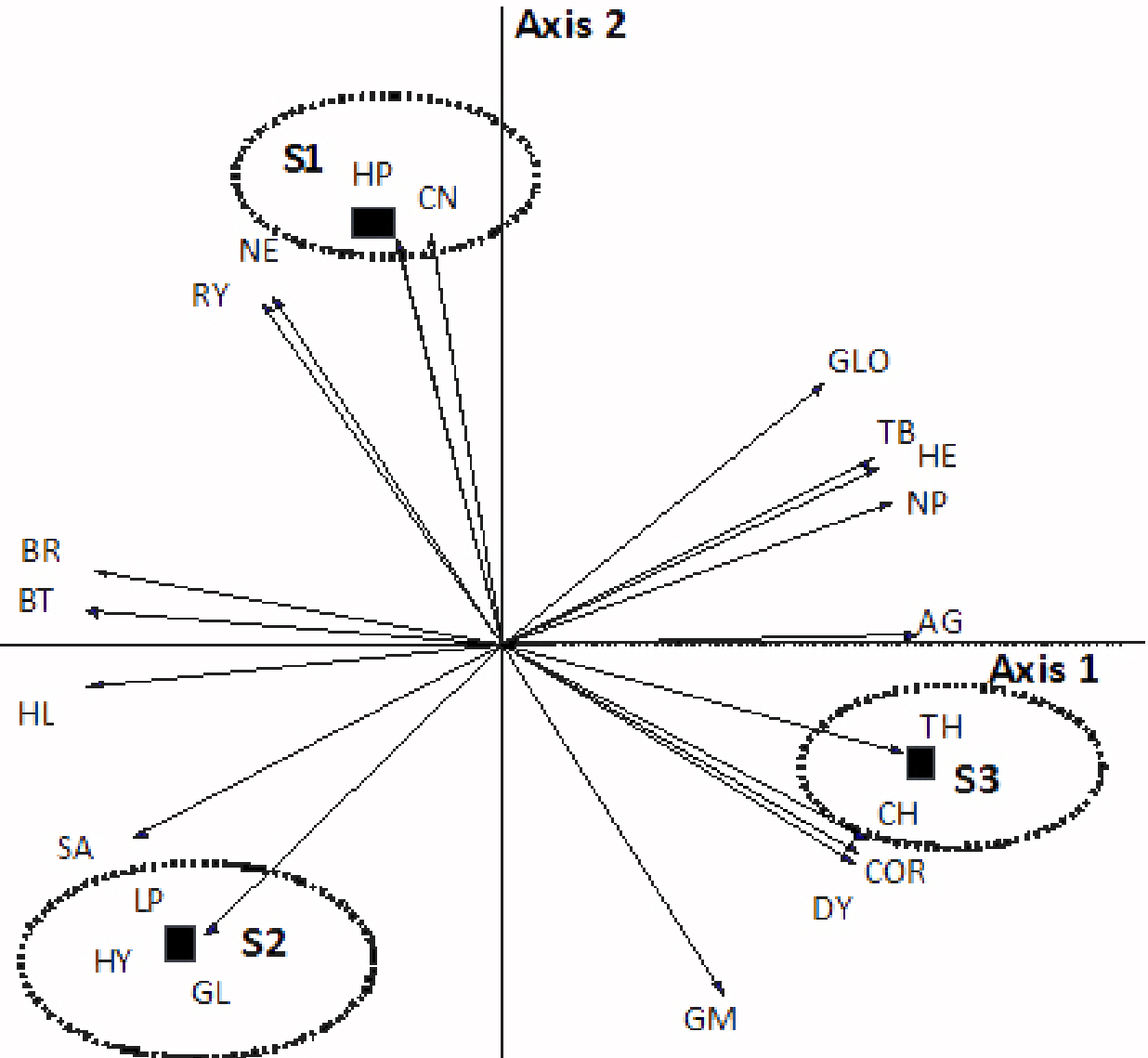

1.5

$-1.5$

Figure 4. Principal Component Analysis (PCA): The ordination indicates the characteristic taxa through graphical presentation between the taxon (arrows) and station as well as each land use (filled square) in the river Ken. The taxa close to the station are characteristic of that station and encircled.

Acronyms: AG - Agrionida; BT - Baetidae; BR - Brachycentridae; CH - Chironomidae; CN - Caenidae; COR - Corbiculidae; DY - Dytiscidae;

GM - Gomphidae; GL - Glossosomatidae; GLO - Glossocolecidae; HE - Heleidae; HP - Heptageniidae; HL - Hydroptilidae; HY - Hydropsychidae; LP - Leptophlebiidae; NE - Neoephemeridae; NP- Nepthydae; PR - Perlidae; RY - Rhyacophilidae; SA - Salifidae; TB - Tabanidae; TH - Thiaridae' 


\section{DISCUSSION}

Differences in the patterns of land use along the river course elicit different responses from the benthic macroinvertebrate communities (Walsh et al. 2001; Wilson et al. 2007) that are unknown for the rivers of Bundelkhand region (central India). Three different patterns of land use occur along the Ken River in Bundelkhand Plateau;

1) 'semi-natural' in the upper part of the river,

2) 'urban' in the middle stretch of the River Ken and

3) 'extensive agriculture' and small habitations in the lower stretch.

Examination of macroinvertebrate communities in these land uses along the course of the Ken shows a slightly higher density in the semi-natural land use at S1 compared to moderate density in agriculture land use (S3) and least in urban landuse at S2. However, the faunal richness declines marginally from semi-natural (15 taxa) to urban land use (14 taxa), but declines notably in agricultural land use (12 taxa) indicating the impact of the landuse. The invertebrate density is known to be higher in agricultural streams than forest streams (Lenat 1984; Harding \& Winterbourn 1995; Mishra \& Nautiyal 2011) and least in the urban land use streams (Hilsenhoff 1988; Novak \& Bode 1992; Paul \& Meyer 2001; Walsh et al. 2001; Stepenuck et al. 2002; Wang \& Kanehl 2003; Fleituch 2003; Mishra \& Nautiyal 2011, 2013; Nautiyal \& Mishra 2012) as observed in the present study also. Longitudinally, benthic macroinvertebrate density usually increases from headwater to mouth (Nautiyal 1997; Kownacki et al. 2000; Younes-Barailla et al. 2005; Milesi et al. 2009), but has been observed to decrease in the plateau rivers of Bundelkhand region (Mishra \& Nautiyal 2012; Nautiyal \& Mishra 2012). Richness increases in mountain rivers (Singh et al. 1994) and decreases in plateau rivers (Mishra \& Nautiyal 2011, 2012; Nautiyal \& Mishra 2012). Least density in the middle stretch (S2) in respect of the upper (S1) and lower (S3) stretch shows that the urban landuse causes abrupt decrease in density and disrupts the longitudinal pattern of gentle decrease. In contrast, the richness was scarcely affected in the Ken. This indicates that urban land use at S2 does not completely shadow the natural gradients in the Ken.

Notably higher densities of Neoephemeridae and Caenidae at S1 decline at downstream locations. These taxa prefer boulder-rock substrate (Aagaard et al. 2004; Mishra \& Nautiyal 2011), and are hence present and abundant only at S1. Since both function as collectors, their abundance at S1 in semi-natural land use suggests heterotrophic state due to fine particulate organic matter (FPOM) from agriculture (left bank) and coarse particulate organic matter (CPOM) from forest (right bank) at S1. High densities of Leptophlebiidae and Hydropsychidae and moderate density of Baetidae occur at S2 only as they prefer smaller particle size viz. cobble-pebble and stony gravel habitat (Czachorowski 1989; Nautiyal \& Mishra 2012). Further, their function as gathering collectors in the urban land use is justified due to sewage derived particulate organic matter (POM) at S2. The abundance of Hydropsychidae is associated with organic pollution (Barbosa et al. 2001; Mayenco \& Ruíz 2007) and stable water flow (Georgian \& Thorp 1992). Subramanian et al. (2005) also observed high abundance of Hydropsychidae (Hydropsyche and Macronema), Baetidae (Baetis) and Leptophlebiidae (Isca and Choroterpes) in the human modified riparian land use types of Western Ghat streams.

The station S3 lies in the mouth zone of the river where the substrate particle size reduces to silt-clay. Therefore, Thiaridae a scraper, Chironomidae a gathering collector and Nephthydae a filtering collector that prefer soft sediments are abundant at S3. The collectors are dominant from S1 to S3. However, as compared with upstream locations, the number of scrapers increased notably at S3 due to an increased abundance of Thiaridae (Table 3). The nutrients from agriculture proliferates growth of macrophytes on which the scrapers Thiaridae (Mesogastropoda) and Gomphidae (Odonata) anchor and feed. The FPOM from the agriculture land use serves as food for gathering and filtering collectors as also observed by Miserendino (2001) and Kerans et al. (2005) in plateau and temperate rivers, respectively. The abundance of gathering and filtering collectors in agricultural land use has been observed in the Paisuni also (Mishra \& Nautiyal 2011). Thus, the composition of benthic macroinvertebrate fauna, assemblages and functional feeding groups vary in these different land use patterns (Table 2). The ordination technique also reflects change in the characteristic taxa due to land use.

This suggests that natural variability (substrate type and its heterogeneity vis-à-vis continuum) and differences in POM; (land use as source of detritus) govern the taxa richness, density, current faunal composition and characteristic taxa at respective locations. These community features are influenced by the modified riparian land use types as also observed from many temperate streams (Fontaine et al. 1990; Hershey \& Lamberti 1998; Buffagni \& Gomba 1996). The abundance of collectors all along the rivers indicates heterotrophic state due to allochthonous food resource 
primarily from agriculture sources in the Ken river (lowerorder river $>3^{\text {rd }}$ order; <http://creekconnections. allegheny.edu/Modules/On- line Activities/Topographic Maps/Stream Order.pd $>f)$. This is in contrast to the river continuum concept (Vannote et al. 1980) where lower order streams, similar to those considered in this study, should present a relatively high density of shredders, of about $30 \%$ of proportional abundance. However, no shredders were found in this study. This finding should be interpreted considering the framework in which this concept was developed. In its original postulation the concept considered a river system with headwater streams (order 1-3) flowing through forested regions with headwaters heavily shaded and abundant leaf litter input from the riparian forest leading to a relatively high density of shredders. On the contrary, the headwater of the Ken flows through the agriculture land use; one side agriculture and other side forest (Image. 1a). In this stream the input of organic matter from agriculture is noticeably less significant than in forested streams, accounting for the absence of shredders. Moreover, as the studied stream is not canopied, and should have more autochthonous production similar to the production expected for middle order streams in forested river systems, according to the river continuum concept. But the heterotrophic condition prevails because the existing land use masks natural gradients varyingly due to high inputs of POM from human impacted land use resulting in the abundance of collectors (gathering collectors). Bennett (1998) also observed an abundance of collectors in the agriculture dominated stream. However, in the present study the share of collectors seem to be low because of cumulative increase of nutrients in the lower reach from agriculture land use and result in gradual increase of scrapers.

It is safe to say that the land use affects the function (predominance of collectors), while the continuum due to substrate governs the structure, and helps to distinguish the impacted and reference localities. Each land use has characteristic taxa. Dudgeon (1999) argues that in tropical Asia it is difficult to distinguish changes due to human impact from changes resulting from natural variability at various spatial and temporal scales. However, in our opinion if human activity is intense the impact will be visible in tropical conditions also. The changes in faunal composition show disruption of the river continuum due to anthropogenic stress and agricultural practices. Besides, it is important to distinguish the changes due to impact of land use from those due to natural landscape and associated factors like the physico-chemistry of water and the substrate conditions (Ross \& Wallace
1982; Greenwood \& Mclntosh 2004; Díaz et al 2008; Mishra \& Nautiyal 2011, 2012; Nautiyal \& Mishra 2012).

\section{CONCLUSION}

The longitudinal gradients in the physico-chemistry of water and substrate account for changes in density, richness and faunal composition. These changes reflect disruption of the river continuum due to human modified riparian land use. The functional role of the community modifies under the influence of surrounding land use. The River Ken is functionally heterotrophic all along its length, as predicted for the natural stream of RCC (River Continuum Concept) up to $1^{\text {st }}-3^{\text {rd }}$ order stream, primarily applicable to neacrtic streams where collectors and shredders dominate functionally. The river lacks shredders due to a lack of forest canopy and prevalence of agriculture.

\section{REFERENCES}

Aagaard, K., J.O. Solem, T. Bongard \& O. Hanssen (2004). Studies of aquatic insects in the Atna River 1987-2002. Hydrobiologia 521: 87-105; http://dx.doi.org/ 10.1023/B:HYDR.0000026352.40631.37

Allan, J.D. (2004). Landscapes and riverscapes: the influence of land use on stream ecosystems. Annual Review of Ecology, Evolution and Systematics 35: 257-284; http://dx.doi.org/10.1146/annurev. ecolsys.35.120202.110122

Barbosa, F.A.R., M. Callisto \& N. Galdean (2001). The diversity of benthic macroinvertebrates as an indicator of water quality and ecosystem health: a case study for Brazil. Aquatic Ecosystem Health and Management Society 4: 51-59; http://dx.doi.org/ 10.1080/146349801753569270

Bennett, B.L. (1998). Land use influences on benthic invertebrate assemblages in southern Appalachian agricultural streams. Master of Science Thesis, Virginia Polytechnic Institute and State University, Virginia, 106pp.

Braak, C.J.F.T \& P. Smilauer (2002). CANOCO Reference Manual and Canodraw for Windows User's Guide: Software for Canonical Community Ordination (version 4.5). Microcomputer Power (Ithaca, NY, USA).

Buffagni, A. \& T. Gomba (1996). Larval development and ecology of Baetis liebenauae Keffermüller (Ephemeroptera: Baetidae) in a north Italian lowland spring. Annales de Limnologie Limnology 32(4): 221-228; http://dx.doi.org/10.1051/limn/1996020

Corkum, L.D. (1989). Patterns of benthic invertebrate assemblages in rivers of northwestern North America. Freshwater Biology 21: 191205; http://dx.doi.org/ 10.1111/j.1365-2427.1989.tb01358.x

Corkum, L.D. (1991). Spatial patterns of macroinvertebrate distribution along rivers in eastern deciduous forest and grassland biomes. Journal of North American Benthological Society 10(4): 358-371.

Cotta-Ramusino, M., S. Villa \& D. Calamari (1995). River continuum concept and correspondence analysis to study Alpine stream macroinvertebrate assemblage. MemoriedII'Istitutoltaliano di Idrobiologia 53: 101-114.

Cummins, K.W., R.W. Merritt \& C.N. Andrade (2005). The use of invertebrate functional groups to characterize ecosystem attributes in selected streams and rivers in south Brazil. Studies on Neotropical Fauna and Environment 40(1): 69-89; http://dx.doi. 
org/10.1080/01650520400025720

Czachorowski, S. (1989). Differentiation of the habitats of Hydropsychidae larvae (Insecta: Trichoptera) in the Pasteka River as a result of avoidance of trophic competition. Polish Archiv für Hydrobiologie 36: 123-132.

Díaz, A.M., M.L.S. Alonso \& M.R.V. Gutiérrez (2008). Biological traits of stream macroinvertebrates from a semi-arid catchment: patterns along complex environmental gradients. Freshwater Biology 53: 1-21; http://dx.doi.org/10.1111/j.1365-2427.2007.01854.x

Dudgeon, D. (1999). Tropical Asian Streams-Zoobenthos, Ecology and Conservation. Hongkong University Press, Hongkong, 828pp.

Edington, J.M. \& A.G. Hildrew (1995). Caseless caddis larvae of the British Isles. Freshwater Biological Association Scientific Publication 53: 1-133.

Edmondson, W.T. (1959). Freshwater Biology - $2^{\text {nd }}$ Edition. John Wiley and Sons, INC, New York, 1248pp.

Fleituch, T. (2003). Structure and functional organization of benthic invertebrates in a regulated stream. International Review of Hydrobiology 88 (3-4): 332-344; http://dx.doi.org/ DOI: 10.1002/ iroh.200390029

Fontaine, J., E. Castella \& A. Nelva (1990). Some aspects of the ecology of Leptophlebia vespertina (L.) (Ephemeroptera: Leptophlebiidae), pp. 275-280. In: Campbell, I.C. (ed.). May Flies and Stone Flies. Kluwer Academic Publishers.

Georgian. T. \& J.H. Thorp (1992). Effects of microhabitat selection on feeding rates of netspinning caddisfly larvae. Ecology 73: 229-240; http://dx.doi.org/10.2307/1938734

Greenwood, M.J. \& A.R. McIntosh (2004). Influence of environmental conditions on nymphal development and abundance of Deleatidium fumosum mayflies. New Zealand Natural Sciences 29: 55-66

Harding, J.S. \& M.J. Winterbourn (1995). Effects of contrasting land use on physico-chemical conditions and benthic asssemblages of streams in a Canterbury (South Island, New Zealand) river system. New Zealand Journal of Marine and Freshwater Research 29: 479492.

Hershey, A.E. \& G.A. Lamberti (1998). Stream macroinvertebrate communities, pp. 169-199. In: Naiman, R.J \& R.E. Bilby (eds.) River Ecology and Management-Lessons from the Pacific coastal ecoregion. Springer-Verlag, New York.

Hilsenhoff, W.L. (1988). Rapid field assessment of organic pollution with a family-level biotic index. Journal of the North American Benthological Society 7: 65-68.

Jüttner, I., S. Sharma, B.M. Dahal, S.J. Ormerod, P.J. Chimonides \& E.J. Cox (2003). Diatoms as indicators of stream quality in the Kathmandu valley and middle hills of Nepal and India. Freshwater Biology 48: 2065-2084; http://dx.doi.org/10.1046/j.1365-2427.2003.01138.x

Kerans, B.L., M.F. Dybdahl, M.M. Gangloff \& J.E. Jannot (2005). Potmopyrgus antipodarum: distribution, density and effects on native macroinvertebrate assemblages in the Greater Yellowstone ecosystem. Journal of North American Benthological Society 24(1): 123-138; http://dx.doi.org/10.1899/08873593(2005)024<0123:PADDAE >2.0.CO;2

Kownacki, A., M. Margreiter, B. Kawecka \& J. Kwandrans (2000). Effect of treated wastes on cyanobacteria, algae and macroinvertebrate communities in an alpine stream. Acta Hydrobiologia 42(3/4): 215230.

Lenat, D.R. (1984). Agriculture and stream water quality: a biological evaluation of erosion control practices. Environmental Management 8: 333-344; http://dx.doi.org/ 10.1007/BF01868032

Mayenco, A.G. \& A. Ruíz (2007). Distribution and microhabitat selection of Hydropsyche exocellata Dufour (Trichoptera, Hydropsychidae) in a Mediterranean river affected of organic pollution: the Guadaira River (S. Spain). Limnetica 26 (1): 89-97

Milesi, S.V., C. Biasi, R.M. Restello \& L.U. Hepp (2009). Distribution of benthic macroinvertebrates in Subtropical streams (Rio Grande do Sul, Brasil). Acta Limnology Brasil 21(4): 419-429.

Minshall, G.W. (1978). Autotrophy in stream ecosystems. Bio Science 28: 767-771.

Miserendino, M.L. (2001). Macroinvertebrate assemblages in Andean Patagonian rivers and streams: environmental relationships. Hydrobiologia 444: 147-148; http://dx.doi.org/ 10.1023/A:1017519216789

Mishra, A.S. \& P. Nautiyal (2011). Factors governing longitudinal variation in benthic macroinvertebrate fauna of a small Vindhyan River in central highlands ecoregion (central India). Tropical Ecology 52(1): 103-112.

Mishra, A.S. \& P. Nautiyal (2012). Longitudinal Distribution of Benthic Macroinvertebrate Assemblages in a Central Highlands River, The Tons (Central India). Proceedings of the National Academy of Sciences, India Section B: Biological Sciences 83(1):47-51; http:// dx.doi.org/10.1007/s40011-012-0083-4.

Nautiyal, P. (1997). Migratory phenomenon of the endangered Himalayan Mahseer Tor putitora in relation to the Ecology of the river Ganga, 106pp. Final Technical Report of Research Project No. 14/28/92- submitted to the Ministry of Environment and Forests New Delhi under Man and Biosphere, Programme, 85pp.

Nautiyal, P. \& A.S. Mishra (2013). Longitudinal Distribution of Benthic Macroinvertebrate Fauna in a Vindhyan River, India. International Journal of Environmental Sciences 1(3): 150-158.

Nesemann, H., G. Sharma \& R.K. Sinha (2004). Aquatic annelid (Polychaeta, Oligochaeta, Hirudinea) of the Ganga river and adjacent water bodies in Patna (India: Bihar), with description of new leech species (Family Salifidae). Annalen des Naturhistorischen Museum in Wien 105B: 139-187.

Novak, M.A. \& R.W. Bode (1992). Percent model affinity: a new measure of macroinvertebrate community composition. Journal of the North American Benthological Society 11: 80-85.

NWDA (National Water Development Agency) (2006). Terms of Reference for Preparation of the Detailed Project Report: Interlinking of Rivers. <http://nwda.gov.in/writereaddata/linkimages/9.pdf>. Downloaded on 15 March 2007

Ormerod, S.J., S.D. Rundle, S.M. Wilkinson, G.P. Daly, K.M. Dale \& I. Juttner (1994). Altitudinal trends in the diatoms, bryophytes, macroinvertebrates and fish of a Nepalese river system. Freshwater Biology 32: 309-322; http://dx.doi.org/ 10.1111/j.1365-2427.1994. tb01128.x

Paul, J.P. \& J.L. Meyer (2001). Stream in the urban landscape. Annual Review of Ecology and Systematics 32: 333-365; http://dx.doi.org/ 10.1146/annurev.ecolsys.32.081501.114040

Richards, C., G.E. Host \& J.W. Arthur (1993). Identification of predominant environmental factors structuring macroinvertebrate communities within a large agricultural catchment. Freshwater Biology 29: 285-294; http://dx.doi.org/ 10.1111/j.1365-2427.1993. tb00764.x

Ross, D.H. \& J.B. Wallace (1982). Factors influencing the longitudinal distribution of larval Hydropsychidae (Trichoptera) in a southern Appalachian stream system (U.S.A.). Hydrobiologia 96: 185-199; http://dx.doi.org/ 10.1007/BF02185434

Roth, N.E., J. D. Allan \& D. L. Erickson (1996). Landscape influences on stream biotic integrity assessed at multiple spatial scales. Landscape Ecology 11: 141-156.

Singh, H.R. \& P. Nautiyal (1990). Altitudinal changes and the impact of municipal sewage on the community structure of macrobenthic insects in the torrential reaches of the river Ganges in the GarhwalHimalaya (India). Acta Hydrobiologica 32: 407-421.

Singh, H.R., P. Nautiyal, A.K. Dobriyal, R.C. Pokhriyal, M. Negi, V. Baduni, R. Nautiyal, N.K. Agrawal, P. Nautiyal \& A. Gautam (1994). Water quality of the river Ganga (Garhwal Himalayas). Acta Hydrobiologica 36: 3-15.

Stepenuck, K.F., R.L. Crunkilton, \& L.Z. Wang (2002). Impacts of urban land use on macroinvertebrate communities in south eastern Wisconsin streams. Journal of the American Water Resources Association 38: 1041-1051.

Subramanian K.A., K.G. Sivaramakrishnan \& M. Gadgil (2005). Impact of riparian land use on stream insects of Kudremukh National Park, Karnataka state, India. Journal of Insect Science 5: 49.

Unni, K.S. (1996). Ecology of River Narmada. A.P.H. Publishing Corporation, New Delhi, 371pp. 
Vannote, R.L., G.W. Minshall, K.W. Cummins, J.R. Sedell \& C.E. Cushing (1980). The River continuum concept. Canadian Journal of Fisheries and Aquatic Sciences 37: 130-137.

Vombatkere, S.G. (2005). Is linking river an answer to floods and droughts? In National Water Convention (NWC) 2: 228-233.

Walsh, C.J., A.K. Sharpe, P.F. Breen \& J.A. Sonneman (2001). Effects of urbanization on streams of the Melbourne region, Victoria, Australia. Benthic macroinvertebrate communities. Freshwater Biology 46: 535-551; http://dx.doi.org/ 10.1046/j.1365-2427.2001.00690.x

Wang, L.H. \& P. Kanehl (2003). Influences of watershed urbanization and in stream habitat on macroinvertebrates in cold water streams. Journal of the American Water Resources Association 39: 11811196.

Wilson, A.L., R.L. Dehaan, R.J. Watts, K.J. Page, K.H. Bowmer \& A. Curtis (2007). Proceedings of the $5^{\text {th }}$ Australian Stream Management Conference. Australian rivers: making a difference. Charles Sturt University, Thurgoona, New South Wales.

Younes-Baraillé, Y., X. Garcia, \& J. Gagneur (2005). Impact of the longitudinal and seasonal changes of the water quality on the benthic macroinvertebrate assemblages of the Andorran streams. C.R. Biologies 328: 963-976 <http://nhm2.uio.no/norlex/past/ download.html>. 